\title{
PEMBENTUKAN KARAKTER RELIGIUS ANAK SEJAK DINI MELALUI ANIMASI NUSSA
}

\author{
Irwansyah \\ awakimed@gmail.com \\ Universitas Pamulang, Tangerang Selatan
}

\begin{abstract}
Abstrak
Pada penelitian ini menggunakan deskriptif kualitatif dengan tujuan mengetahui bahwa animasi Nussa yang diambil dari yutub Nussa Official dapat membentuk karakter religius anak sejak dini. Analisis data dengan menggunakan teknik observasi, dokumentasi dan studi kepustakaan. Selanjutnya diambil sampel secara acak dari vidio animasi Nussa. Dari hasil penelitian didapat bahwa tokoh-tokoh dalam cerita menunjukkan karakter religius. Religius pada animasi Nussa menujukkan tokoh-tokoh yang islami menyampaikan pesanpesan melalui dialog tokoh secara sederhana melalui tata cara kehidupan islam berupa penerapan dari aturan agama islam. Disamping itu pakaian yang dikenakan tokoh-tokoh animasi tersebut merupakan gambaran yang mewakili pakaian muslim. Ketika religius tokoh Nussa dan tokoh lain terus menerus ditonton anak usia dini melalui animasi Nussa maka akan membentuk karakter mereka. Dari hal-hal tersebut animasi ini layak dijadikan alat untuk membentuk karakter religius anak sejak usia dini.
\end{abstract}

Kata kunci: Karakter, religius, usia dini, media sosial, animasi

\section{Pendahuluan}

Kalau kita berbicara mengenai penyiaran melalui media televisi, maka kita ketahui bahwa penduduk Indonesia sangat akrab televisi. Hampir semua rumah tangga dalam masyarakat Indonesia memiliki televisi atau paling tidak terbiasa menonton siaran televisi. Televisi kemudian menjadi salah satu media penyiaran yang sangat kuat posisinya di masyarakat dengan melihat fakta bahwa penonton televisi di Indonesia sangatlah banyak. 
Televisi adalah salah satu media yang digunakan masyarakat sebagai hiburan dengan berbagai produk. Produk yang dimaksudkan bukan hanya berupa barang, akan tetapi juga mencakup jasa, orang, organisasi, dan gagasan. Produk media penyiaran adalah segala sesuatu yang dapat ditawarkan oleh media penyiaran kepada audience untuk didengar atau ditonton. Ada banyak produk penyiaran seperti sinetron, berita, lawak, musik, infotainment, olahraga, cerita fantasi, kartun, animasi dan lain lain. Huburan yang ditampilkan oleh televisi peruntukannya dapat disesuaikan usia, dewasa, remaja dan anak anak.

Selain televisi sebagai media, ada banyak muncul media lain sering kita sebut media sosial. Media sosial berkembang pesat dari tahun-ketahun sehingga tontonan tidak hanya dari media televisi saja. Perkembangan media sosial seperti yutub yang mudah diakses oleh siapa saja pengguna internet dapat berpengaruh pada perkembangan karakter generasi muda terutama generasi usia dini. Perkembangan teknologi melalui media sosial dapat berpengaruh besar terhadap pembentukan karakter para generasi dengan berbagai berita tindak kekerasan, seksualitas, kenakalan remaja, pencurian, perampokan serta hal hal lain yang mudah diakses oleh para generasi tanpa kontrol yang jelas. Generasi muda menerima segala macam pengaruh dari media massa yang berimbas pada pembentukan karakter mereka.

Perkembangan karakter anak usia dini perlu diperhatikan lebih inten agar tidak terpengaruh oleh hal-hal yang negatif. Untuk mengontrol perkembangan karaktergenerasi maka harus dibentuk dari anak usia dini. Anak anak usia dini mudah mencernah hal-hal baru yang mereka anggap menarik, tetapi anak-anak usia dini tidak dapat menentukan mana hal yang baik mereka serap dan mana hal yang tidak baik. Oleh karena itu orang tua serta masyarakat perlu memperhatikan dan mengawasi tontonan dari media yang ada saat ini. Pengawasan dilakukan mulai memilah milah tontonan apa yang cocok ditonton anak usia dini. Media sosial tidak hanya memberi hiburan negatif tetapi juga banyak memberi hal-hal positif yang bisa pula membentuk generasi yang baik. 
Menurut Kristiawan (2015) bagi Indonesia saat ini, karakter pendidikan juga berarti upaya sungguh sungguh, sistematis dan berkelanjutan membangun dan memperkuat kesadaran dan kepastian bahwa seluruh rakyat Indonesia tidakakan memiliki masa depan yang lebih baik tanpa membangun karakter orang Indonesia. Membangun dan memperkuat kesadaran melalui karakter perlu cara yang tepat dengan sistematis dan terencana. Indonesia sebenarnya telah menetapkan pendidikan karakter yang dimasukkan dalam kurikulum penddidikan.

Menurut R. Megawangi (2004) pendidikan karakter adalah usaha aktif untuk membentuk kebiasaan baik (habit), sehungga sifat anak sudah terukir sejak kecil. Sedangkan menurut M.F. Gaffar (2010) pendidikan karakter adalah sebuah proses transformasi nilai-nilai kehidupan untuk ditumbuh- kembangkan dalam kepribadian seseorang, sehingga menjadi satu dalam perilaku kehidupan orang itu. Pendidikan karakter tidak hanya dibentuk dalam pendidikan formal dapat juga melalui pendidikan non formal maupun pembentukan dalam lingkungan masyarakat.

Berdasarkan kamus besar bahasa Indonesia (KBBI) karakter adalah sifat sifat kejiwaan, akhlak atau budi pekerti yang membedakan seseorang dengan yang lain (tabiat, watak, kepribadian). Karakter berbeda dengan kepribadian karena pengertian kepribadian dibebaskan dari nilai. Ada 18 nilai karakter antara lain: religius, jujur, toleransi, disiplin, kerja keras, kreatif, mandiri, demokratis, rasa ingin tahu, semangat kebangsaan, cinta tanah air, menghargai prestasi, bersahabat/komunikatif, cinta damai, gemar membaca, peduli lingkungan, peduli sosial, dan tanggung-jawab.

Hal tersebut menunjukkan bahwa ada keseriusan pemerintah untuk mempersiapkan generasi melalui pendidikan karakter dengan harapan masa depan para generasi dan masa depan bangsa ini menjadi lebih baik. Keseriusan tersebut harus didukung masyarakat serta orang tua dengan benar benar memperhatikan serta memilah tontonan mana yang baik untuk para generasi yang disesuaikan dengan usia mereka terutama perhatian yang lebih pada anak usia dini. 
Anak usia dini senang mengikuti apa saja yang mereka lihat, mereka akan mencoba mencontohkan dan melakukan langsung dari yang mereka lihat, dengar dan rasakan sehingga mereka sangat rentan terhadap pengaruh hal-hal positif maupun ha-hal negatif. Anak usia dini senang bermain dengan imajinasinya berdasarkan pengaruh dari luar dirinya. Mereka berada pada masa kritis pada perkembangan hidup manusia karena dimasa ini sebagai pembentukan perkembangan anak selanjutnya. Pada masa kritis ini tepat untuk meletakkan dasar bagi kemampuan kognitif, fisik, sosial, agama, bahasa, seni dan nilai-nilai moral.

Menurut UU No. 20 Tahun 2003 Tentang Sistem Pendidikan Anak Usia Dini (PAUD) adalah suatu upaya untuk pembinaan yang ditujukan pada anak usia 0 hingga 6 tahun yang dilakukan melalui pemberian rangsangan atau stimulus pendidikan untuk membantu pertumbuhan dan perkembangan jasmani serta rohani agar anak memiliki kesiapan dalam memasuki pendidikan lebih lanjut. PAUD dapat diselenggarakan melalui jalur pendidikan formal, nonformal dan informal. Melalui pendidikan anak usia dini akan mendapatkan informasi untuk menunbuhkan pengetahuan mereka sehingga siap menjadi manusia sesungguhnya. Selain itu media juga akan membentuk kejiwaan dengan mengisi pengetahuan dengan memanfaatkan seluruh aspek organ manusia dengan koordinasi otak sehingga menemukan hal-hal baru sebagai pengisi memori sekaligus pembentukan pertumbuhan. Selain itu perlu pembentukan karakter religius.

Menurut kamus besar bahasa Indonesia (KBBI) religius adalah bersifat religi, bersifat keagamaan,yang bersangkut paut dengan religi. Religi menurut KBBI adalah kepercayaan kepada tuhan; kepercayaan akan adanya kekuatan adikodrati di atas manusia; kepercayaan (animisme, dinamisme); agama. Karakter religius merupakan sikap dan prilaku yang patuh dalam melaksanakan ajaran agama yang kita anut, toleransi terhadap pelaksanaan ibadah yang dilakukan penganut agama lain, dan hidup berdampingan atau saling rukun dengan penganut agama lain. 
Banyaknya kasus kekerasan, pornografi, narkoba, kejahanan remaja, tawuran, korupsi, minimnya ketahanan keluarga dan lain-lain merupakan tantangan yang berat bagi bangsa Indonesia terutama bagi masyarakat dan orang tua. Hal-hal tersebut sangat mudah kita akses melalui perkembangan teknologi saat ini. Perkembangan teknologi tersebut memunculkan kebiasaan baru dalam media sosial, perilaku kekerasan hingga karakter yang menyimpang sehingga merusak karakter generasi bangsa ini.

Oleh karena itu perlu tontonan dalam media sosial yang dapat membentuk karakter generasi akan datang terutama anak usia dini. Salah satu tontonan yang layak untuk pembentukan karakter religius adalah animasi Nussa melalui yutub pada Nussa Official. Animasi adalah hasil gambar tangan yang dibuat bergerak. Animasi Nussa bagian daricara orang tua untuk menghindari penyimpangan yang dilakukan generasi efek dari media sosial. Seperti pendapat Jannah (2020) animasi Nussa merupakan animasi edutaiment yaitu edukasi dan entertainment, suatu tayangan dapat mempengaruhi prilaku penontonnya sehingga konten-konten di dalamnya harus memuat nilai-nilai pesan dakwah. Animasi ini merupakan animasi anak-anak yang mengandung nilai-nilai positif, dan menjadikan sebuah tayangan yang dapat memberikan edukasi bagi anak-anak.

Penelitian ini penting dilakukan agar masyarakat terutama orang tua menyadari pentingnya pengawasan terhadap tontonan yang didapat baik dari media televisi maupun media sosial agar karakter anak dapat dibentuk dan dikontrol sejak dini sehingga kita dapat menghasilkan generasi yang berkarakter dengan nilai religius.

Berdasarkan penjelasan tersebut penulis menyusun rumusan masalah yaitu bagaimana pembentukan karakter religius anak sejak dini melalui animasi Nussa. Selanjutnya tujuan pada penelitian ini adalah mendeskripsikan pembentukan karakter religius anak sejak dini melalui animasi Nussa. 


\section{Metode Penelitian}

Penulis melakukan penelitian dengan deskriptif yaitu menjelaskan sesuatu sesuai objek yang dianalisis. Objek penelitiannya adalah animasi Nussa dengan pendekatan kualitatif. Pendekatan kualitatif dengan menelusuri secara intensif menggunakan metode kajian pustaka untuk mengumpulkan informasi mengenai karakter religius. Pengumpulan secara intensif tersebut prosedur ilmiah untuk mendapatkan kesimpulan naratif secara tertulis berdasarkan analisis data.

Data dan sumber data diambil dari data lisan dan data tulis. Data lisan berupa rekaman vidio animasi Nussa yang diambil dari yutub Nussa Official. Kemudian data yang di dapat dari lisan ditranskrip dengan mengambil tuturan tuturan yang diduga dapat menanamkan karakter religius. Selanjutnya tuturan yang diduga dapat menanamkan karakter religius anak sejak dini tersebut dijadikan data tulis.

Pada teknik pengumpulan data pada penelitian ini menggunakan teknik observasi, dokumentasi dan studi kepustakaan. Observasi dilakukan dengan melihat rekaman vidio animasi Nussa dari yutub dengan mengamati dialog-dialog berupa pembicaraan antar tokoh atau lagu yang dinyayikan dalam vidio animasi Nussa. Dokumentasi dilakukan untuk mengumpulakn data melalui data tulis seperti arsip, buku teori, jurnal, pendapat, serta dalil yang berhubungan dengan karakter religius. Sedangkan studi kepustakaan dilakukan dengan membaca buku, jurnal dan lain lain yang berhubungan dengan karakter religius. Kemudian analisis data dengan menonton animasi Nussa dengan sampel yang diambil secara acak.

\section{Hasil Penelitian dan Pembahasan}

Animasi Nussa menceritakan dua tokoh utama yaitu Nussa dan Rarra yang hidup sehar-harinya berdasarkan aturan ajaran agama islam. Tokoh Nussa yang tidak memiliki kaki sebelah kiri, menggunakan alat bantu (kaki palsu) berpenampilan sederhana dengan pakaian muslimnya. Cara berpakaian tokoh Nussa menunjukkan tokoh tersebut seorang muslim dengan kopiah putih dan 
menggunakan baju koko. Tokoh Rarra sebagai adik Nussa menggunakan pakaian muslimah ditambah lagi tokoh Umma sebagai ibu dari Nussa dan Rarra juga menggunakan pakaian muslimah sebagai ciri dari penganut ajaran islam. Dari cara berpakaiannya anak-anak usia dini akan masuk dalam dunia kehidupan Nussa yang berdasarkan pada aturan hidup dari agama islam.

Animasi Nussa memiliki banyak pesan. Pesan yang disampaikan oleh animasi Nussa bernilai positif melalui ajaran agama islam. Pesan tersebut dapat dijadikan pedoman oleh orang tua dan masyarakat untuk mengajarkan aturan hidup secara islam dengan harapan aturan yang disampaikan animasi Nussa dapat membentuk karakter religius anak sejakdini. Pembentukan karakter religius melalui animasi Nussa dapat kita temukan pada setiap episodenya. Selain dari pakaian muslim animasi Nussa mengajak kita untuk membiasakan salam, berucap syukur,ikhlas, sabar, berdoa, menolong orang lain dan lain sebagainya. Dapat kita lihat tabel di bawah ini mengenai karakter religius yang dimunculkan pada animasi Nussa.

Tabel 1

Nilai Religius Animasi Nussa Official

\begin{tabular}{|c|c|c|}
\hline No & Judul & Nilai Religius \\
\hline 1 & Belajar jualan & $\begin{array}{l}\text { - } \quad \text { Rejeki itu sudah diatur jadi tidakada kata saingan } \\
\text { - } \quad \text { Nussa menjualkan kue cubit Sifa dan abdul } \\
\text { - Pesan Umma: kita harus meneladani sifat } \\
\text { berdagang Rosul amanah, jujur, dan terpercaya } \\
\text { - } \quad \text { Rarra meminta maaf kepada Sifa dan Abdul } \\
\text { - } \\
\text { Sifa dan Abdul berbagi makanan dengan Rarra } \\
\text { dan Nussa }\end{array}$ \\
\hline 2 & Bundaku & $\begin{array}{ll}\text { - } & \text { Berdoa sebelum makan dan minum } \\
\text { - } & \text { Nussa harus bersabar kata Umma } \\
\text { - } & \text { Sebelum berangkat sekolah ucapkan salam } \\
\text { - } & \text { Istigfar Umma ketika merasa sakit } \\
\text { - } & \text { Tante dewi mengucap salam ketika masuk rumah } \\
\text { - } & \text { Pesan Abah (almarhum) : anak laki harus menjadi } \\
& \text { pelindung bagi keluarganya } \\
\text { - } & \text { Mengucapkan alhamdulillah atas keberhasilan }\end{array}$ \\
\hline
\end{tabular}




\begin{tabular}{|c|c|c|}
\hline & & $\begin{array}{l}\text { - Umma tak pernah mengeluh } \\
\text { - } \quad \text { Berdoa agar masuk surga } \\
\text { - } \quad \text { Mandiri (tidak bergantung pada orang lain) } \\
\text { - } \quad \text { Massyaallah diucapkan Umma ketika Nussa } \\
\text { berhasil mandiri } \\
\text { - Umma ikhlas dan tulus memberi apapun untuk } \\
\text { Nussa dan Rarra } \\
\text { - } \quad \text { Berdoa agar dalam lindungan Allah SWT }\end{array}$ \\
\hline 3 & Rarra Sakit & $\begin{array}{l}\text { - Rarra dan Nussa mengucap salam ketika mau } \\
\text { masuk rumah } \\
\text { - } \text { Bismillah ketika mau makan } \\
\text { - Nussa mengucap astagfirrullah ketika kaget } \\
\text { melihat Rarra } \\
\text { - Kalau bersin mengucap alhamdulillah bagi yang } \\
\text { mendengar mendoakan dengan yahamulkumullah } \\
\text { wayusri balakum } \\
\text { - Ada adab bersin } \\
\text { - Umma astagfirullah ketika melihat Rarra sakit } \\
\text { - Demam itu mengahapus dosa }\end{array}$ \\
\hline 4 & Nusa Bisa & $\begin{array}{l}\text { *Nussa tidak memiliki kaki sebelah kiri sejak lahir } \\
\text { (menggunakan alat bantu) tapi keinginnan untuk bermain } \\
\text { bola sangat kuat dan terus berjuang sampai Umma } \\
\text { menanda tangani formulir bermain bola } \\
\text { - Terima kasih Umma kata Nussa saat Umma menanda } \\
\text { tangani formulir main bola } \\
\text { - Umma percaya kalau Nussa bisa } \\
\text { - Nussa mengucapkan assalamualaikum ketika mau } \\
\text { berangkat bermain bola kemudian dia mengucapkan } \\
\text { bismillahirrohmanirrohim }\end{array}$ \\
\hline 5 & Toleransi & $\begin{array}{l}\text { - Nussa dan Rarra menbantu orang ketika } \\
\text { barangnya terjatuh } \\
\text { - Terimakasih (oarng yang dibantu Nussa dan } \\
\text { Rarra) } \\
\text { - Nussa dan Rarra ikhlas membantu } \\
\text { - Puji Tuhan semoga Tuhan memberkati (kata orang } \\
\text { yang dibantu Nussa dan Rarra) } \\
\text { - Astagfirullah ucap Umma ketika mendengar } \\
\text { rumah Ci Memey terbakar }\end{array}$ \\
\hline
\end{tabular}




\begin{tabular}{|c|c|c|}
\hline & & $\begin{array}{l}\text { - Alhamdulillah ketika semua selamat } \\
\text { - Umma menyumbang pakaian untuk Ci Memey } \\
\text { - Rarra menyumbang tas sekolahnya dan Nussa } \\
\text { menyumbang buku tulis dan pensil (untuk } \\
\text { Lingling dan Aloy anak Ci Memey }\end{array}$ \\
\hline 6 & Rukun Islam & $\begin{array}{l}\text { - Lima rukun Islam: 1. Syahadat, 2.Shalat, 3. Puasa, } \\
\text { 4. Bayar Zakat, 5. Naik haji jika sudah mampu } \\
\text { - Rukun islam amalkan, tanamkan dalam hati agar } \\
\text { Allah cinta kita }\end{array}$ \\
\hline 7 & Lomba Traktir & $\begin{array}{l}\text { - Massyaallah pahala mentraktir teman, kata pak } \\
\text { Ustadz kita terhindar dari neraka sejauh tujuh } \\
\text { varian } \\
\text { - Diberi makan mengucap alhamdulillah } \\
\text { - Kata pak Ustadz, Rasul menyukai orang-orang } \\
\text { yang memberi makan saudaranya karena } \\
\text { pahalanya besar }\end{array}$ \\
\hline 8 & Belajar Ikhlas & 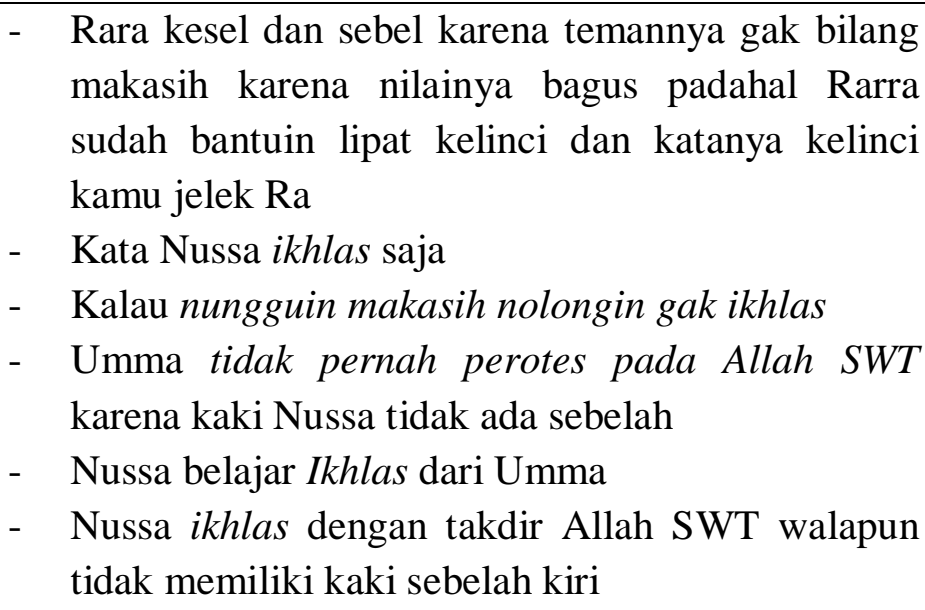 \\
\hline 9 & Hii Serem & $\begin{array}{l}\text { - } \begin{array}{l}\text { Assalamualaikum Umma } \\
\text { - }\end{array} \text { Takjiah...siapa yang meninggal Umma } \\
\text { - } \text { Astagfirullah allazim (terkejut ketika anta kucing } \\
\text { milik Nussa mengejutkan) } \\
\text { - } \text { Rarra meminta maaf ketika menginjak ekor anta } \\
\text { - } \text { Ketika mati lampu Nussa berucap astagfirullah } \\
\text { allazim } \\
\text { - Auzubillahiminassyaitonirrozim diucapkan Rarra } \\
\text { dan Nussa ketika ada Abdul buka pintu saat mati } \\
\text { lampu } \\
\text { - Abdul minta maaf karena telah mengejutkan } \\
\text { Nussa dan Rarra } \\
\text { Kata Umma: masyaallah tak ada yang perlu }\end{array}$ \\
\hline
\end{tabular}




\begin{tabular}{|c|c|c|}
\hline & & $\begin{array}{l}\text { ditakuti dari orang yang meninggal } \\
\text { - Dalam Surat Al Imron ayat } 185 \text { tiap-tiap yang } \\
\text { berjiwa akan merasakan mati, hanya saja banyak } \\
\text { dari kita yang lalai dalam mempersiapkan diri } \\
\text { untuk menyambut ajal } \\
\text { - Semua yang meninggal akan dibangkitkan pada } \\
\text { hari kiamat manusia akan } \\
\text { mempertanggungjawabkan perbuatannya selama } \\
\text { didunia } \\
\text { Jadi tak perlu takut pada orang yang sudah mati, } \\
\text { justru mereka mengharapkan doa dari anak } \\
\text { cucunya karena kalau seseorang meninggal dunia } \\
\text { maka terputuslah amalannya kecuali tiga perkara } \\
\text { yaitu, sedekah jariah, ilmu yang bermanfaat, dan } \\
\text { doa anak yang sholeh }\end{array}$ \\
\hline 10 & Di Rumah Aja & 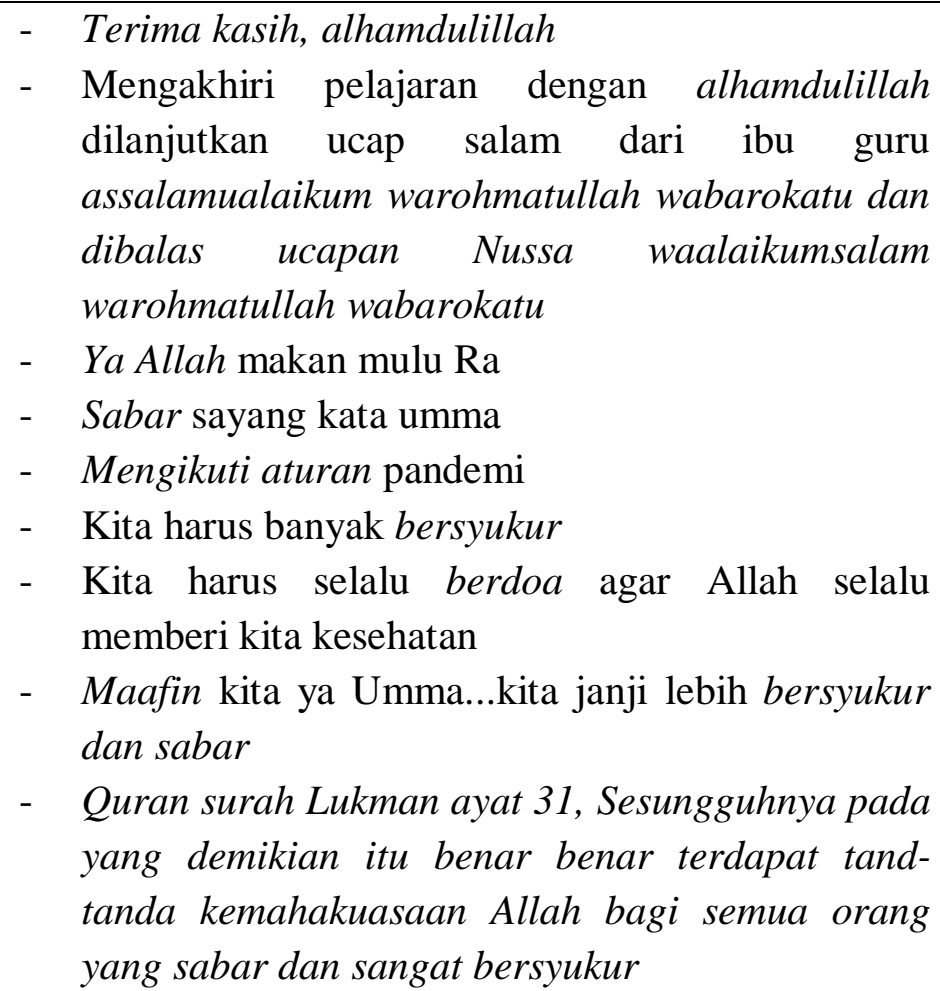 \\
\hline 11 & Shalat Itu Wajib & $\begin{array}{l}\text { - Assalamualaikum ketika Nussa masuk kamar } \\
\text { Rarra } \\
\text { - Nussa: assholatukhoirumminannaum (sholat lebih } \\
\text { baik daripada tidur), dilakukan Nussa ketika } \\
\text { membangunkan rarra untuk sholat subuh } \\
\text { - } \quad \text { Alhamdulillah anak Umma sudah pada bangun } \\
\text { - Shalat bukan masalah rajin, melainkan sholat itu }\end{array}$ \\
\hline
\end{tabular}




\begin{tabular}{|l|l|}
\hline & wajib \\
& - Amalan yang pertama kali dihisab adalah shalat \\
& wajib \\
& - \\
& Shalat sunnah melengkapi Shalat wajib yang \\
& kurang sempurna \\
& - Berangkat mengucapkan salam, assalamualaikum \\
\hline
\end{tabular}

Dari sampel yang kita ambil dari sebelas judul episode pada animasi Nussa menunjukkan bahwa animasi ini merupakan animasi anak-anak dengan tingkah laku kebanyakan anak-anak dengan dibalut ajaran agama islam. Setiap episode selalu menunjukkan religius semua tokoh terutama tokoh Nussa, Rarra dan Umma.Alur cerita pada setiap episode menuntun kita untuk menuju pada halhal positif sehingga animasi ini sangat cocok untuk jadi tontonan yang menjadi tuntunan bagi anak usia dini.

Tuntunan yang disampaikan akan membentuk karakter. Karakter yang sangat menonjol dalam tiap episode adalah karakter religius. Sikap religius para tokoh animasi Nussa akan menggiring anak usia dini untuk melakukan hal sama dilakukan para tokoh sehingga pembentukan karakter religius anak usia dini dapat terbentuk dengan sendirinya. Dengan animasi Nussa melalui media yutub akan mempengaruhi prilaku, sikap dan karakter anak melalui mendengar, melihat, dan mengamati. Tanpa disadari anak belajar secara tradisional (sosial learning) dengan langsung menonton dan mempraktekkan berdasarkan apa yang mereka dengar, lihat dan amati.

\section{Simpulan}

Berdasarkan data yang kita dapat dari animasi Nussa melalui yutub Nussa Official melalui dialog serta gambararan para tokoh, cara berpakain serta bahasa yang digunakan menunjukkan bahwa animasi Nussa berdasarkan kehidupan sehari-hari masyarakat muslim. Ada banyak kata atau kalimat yang menunjukkan karakter religius tokoh yang mengikuti aturan atau norma-norma islam sebagai gambaran kehidupan penganut agama islam. Pengucapan salam ketika masuk dan 
keluar rumah akan menuntun anak usia dini untuk membentuk karakter religius. Berdoa sebelum makan dan minum dilakukan tokoh menunjukkan kebiasaan yang dilakukan ummat muslim ini dapat membentuk karakter religius anak sejak usia dini.

Karakter religius berupa toleransi terhadap pelaksanaan ibadah yang dilakukan penganut agama lain, dan hidup berdampingan atau saling rukun dengan penganut agama lain ditunjukkan tokoh Nussa dan Rarra pada episode Toleransi. Toleransi juga dilakukan oleh Umma untuk membantu Ci Memey dan anak-anaknya akibat rumahnya kebakaran.

Karakter religius lain dapat diambil dari beberapa episode yang menunjukkan aturan hidup islam menyampaikan ayat al quran sebagai kitab suci seperti surah Lukman ayat 31 pada episode Di Rumah Aja dan Surah Al Imron ayat 185 pada episode Hii Seram. Hal ini menuntun kita sebagai orang tua dan masyarakat bahwa pembentukan karekter religius dapat diajarkan melalui animasiNussa. Ayat al Quran menjadi dasar bagi umat islam dalam menjalankan keyakinan, peribadatan serta ahlak mulia.

\section{Daftar Pustaka}

Jannah, Maisal.2020.Keteladanan Tokoh Dalam Serial Animasi Nussa Official.Jurnal Peurawi, vol. 3 No.2

Kamus Besar Bahasa Indonesia.2008.Edisi IV.Jakarta:Balai Pustaka.

Kristiawan, M.2016.Telaah Revolusi Mental dan Pendidikan Karakter Dalam Pembentukan Sumber Daya Manusia Indonesia yang Pandai dan Berakhlak Mulia. Ta'dib,18(1),13-25

M.F. Gaffar, 2010. Pendidikan karakter berbasis Islam (disampaikan pada Workshop Pendidikan Karakter Berbasis Islam)

R. Megawangi. 2004. Pendidikan Karakter Solusi yang Tepat Untuk Membangun Bangsa.Indones.Herit.Found

Undang-undang No. 20 Tahun 2002 Tentang Sistem Pendidikan Nasional. Sistem pendidikan Nasional. Jakarta:CV Tamita Utama. 